\title{
BHIKHU PAREKH CRITICS TOWARD MODERN PLURALISM
}

\author{
Fejrian Yazdajird Iwanebel \\ UIN Sunan Ampel Surabaya \\ iwanebel@gmail.com
}

\begin{abstract}
Pluralism is judged by some thinkers as a response to their dissatisfaction with monism. The factual realities have made a self-evident that society's culture is plural. In this paper the author tries to describe three prominent figures who discuss about pluralism and the weaknesses of their thoughts. The author stands on the work of Bhikhu Parekh entitled "Rethinking Multiculturalism; Cultural Diversity and Political Theory". In Parekh's view, the three thinkers have criticized monism and wanted to propose the idea of cultural pluralism. Unfortunately, they are stuck on moral values which are integral and universal. So they are just returning to moral monism in explaining the reality of a diverse society. In this dialect, multiculturalism becomes a new alternative for intercultural dialogue that carries the mission of equality and freedom of expression which is accompanied by positive reciprocity leading to a dynamic civilization of constructive human life.
\end{abstract}

Key words: Bhikhu Parekh, Monism, Pluralism, Multiculturalism.

\section{A. Introduction}

I $\mathrm{t}$ began from the awareness about imperfection of moral monism. Modern thinkers began to think to redefine the ideal concept of life paradigm to view of culture. As it is known that monism's moral weakness will not only lead to exclusiveness claims, but It will also facilitate the continued status quo and authoritarianism, and make static world history. One form of thought formulated by modern thinkers leads to a view of pluralism. This pluralism expresses a plural view, where human life always follows the stream of change accompanied by the emergence of differences. The difference itself is a genuine character of human being that has reason and unique characteristics. Therefore there are many entities in this life. It is a factual evidence that the view of monism is contrary to reality.

The emergence of pluralism in the modern thought is not necessarily a synthesic solution for the dialectic of monism thought. However, in modern pluralism there are also many weaknesses that actually backfire for this view. So pluralism, in this case, raises two questions about its multiple positions: whether pluralism becomes a "synthesis" of 
monism's moral dialectics, or becomes "antithetical". When pluralism becomes synthesis, then pluralism is the desired answer in seeing reality. But if pluralism becomes antithetical, then the dialectic of reality still continues and leaves the question of what is the synthesis of moral monism and pluralism.

The discussion of pluralism has inspired the author to stands on the thought of Bikhu Parekh which is contained in his work "Rethinking Multiculturalism; Cultural Diversity and Political Theory". The author sees that Bikhu Parekh is one of the most critical thinkers who see the dynamics of reality and the thoughts that arise in them.

\section{B. The outlook of Modern philosopher on Pluralism}

The discussion of pluralism in the modern era will involve some thinkers who contributed to basics of pluralism idea. They are Vico, Montesque, and Herder. According to Bhikhu Parekh, these three thinkers have studied the monism model, and they disagree with it. Therefore, they propose a new thesis as a critique of the monism of pluralism.

\section{Vico}

Vico is a philosopher who lived within the span of historical changes, seventeenth and eighteenth centuries. His thinking has much to say about human problems in his history. He has a fundamental view that every society has its own uniqueness. ${ }^{1}$ This uniqueness is a sign of diversity in society. This diversity is a necessity because they live in different environments comparing with another. Internal and eksternal factors of society become a driving force of diversity within society.

The culture of society sometimes has quite striking differences. Javanese culture is different from Sundanese culture, Madurese, Ambon, Aceh and so on. In Javanese society too, divided into many local cultures that live in together. At least we can use Clifford Geertz's thesis classifying the social complexity of the Javanese society which is divided into three: Abangan, Santri and priyayi.This division actually still becomes a starting point to look deeper a cultural diversity in Java. There are many elements and variables which can be used to track this diversity. For example, if we trace with the religio-anthropology model then there will we find Samin Community, Kalang society, and Pengestu group also, and so forth. All this is a sign that culture has a pluralistic nature. This view is the beginning of the Vico discussion to criticize monism.

Vico's argued that there are many causes for change and diversity that has always been arising in society, including geographical, historical, understanding, worldview, and the principles held by every society. ${ }^{2}$ Naturally these factors contribute to the change and then create a system of beliefs, customs and social classes that exist in the community

\footnotetext{
${ }^{1}$ Bhikhu Parekh, Rethinking Multiculturalism Cultural Diversity and Political Theory, (Cambridge: Harvard University Press, 2000), 50.

${ }^{2}$ Ibid., 50.
} 
order. The formation of this historical and natural social system of culture leads to a thesis that a culture will have difficulty if it is applied in other people's habits. This is because every society has its own history which in sustainability is not the same with each other. So Vico as xplained by Parekh asserts:

"Different societies represented different and often incompatible forms of thought and life. The values and ideals of one could not be combined with those of another, and the kinds of virtues, literature, arts and heroism that flourished in one society were often impossible in another...

Human nature was a product of history not a transhistorical substance, and was differently developed and expressed in different epochs and societies." 3

The development of a society based on this diversity makes it difficult for us to understand the community. The difficulty arises because the reality of society is already integrated with the understanding, thought and nature that the conscious of the deepest. Understanding that which then form a reality of cultural society which becomes a habit that is not realized collectively (collective unconsciousness). In these circumstances human beings have transcended themselves in culture, their behavior has been mixed in the belief system and culture. In Vico's view, since the whole society is integrated by a certain principle, then the ratio goes through the difficulty of reaching it. Because the principle is integral in belief systems and community practices that are difficult to identify. We need to deeply explore the community, feel, and become part of society to understand the structure, ethos, and imagination that is present in it.

Vico's view of integration is what Parekh has criticized. Integration is a general principle that controls the overall values existing in society. So it can be said that this general principle that uniform value in social culture. With this paradigm, it will indirectly bring up the so-called dominant culture and minor culture (little culture). In the cultural hierarchy, it is clear that dominant culture will dominate other cultures. And this view reverses the factuality of his thinking about pluralism. Thus, Vico returned to the original idea that carries the paradigm of monism, namely the existence of a common value that is used as the basis by all cultural values.

To clarify this view, Vico has divided human development into three: 1) the age of gods. In this age, human rationality did not developed, only the fear of the power of the god that played an important role in determining their attitude and behavior. 2) the age of heroism. In this period the spirit of appreciation between people began to develop. And 3) the human age. It is the last and final development in human life. Ratio and awareness of

\footnotetext{
${ }^{3}$ Ibid., 51.
} 
the responsibilities of life have a significant development. By their ration, they are aware of the equality value among humans, resulting in mutual tolerance. Based on the three ages above, Vico underscored that the golden age is in the third time, and according to him it began in Europe marked by the emergence of the Roman Republic. ${ }^{4}$

In the case of a significant developmental of human ratios, Vico asserts that in such developments there must be a counterweight which is found in religion. Because the ratio will generally present individualism, skepticism and barbarism.Therefore, religion will provide a kind of spiritual injection that will strengthen their vision of life. In this case Vico, once again asserted that the religion which can be used as a benchmark is Christian. Because according to him in the religion is covered all the elements that exist in the "human age". He stated:

"christianity was the only 'true' religion because, among other things, it rested on an 'infinitely pure and perfect idea of God', articulated a noble and noninstrumental vision of the highest good, contained truths so profound that they attracted the 'most learned philosophers of the gentiles', and reconciled the 'wisdom of revealed authority with that of reason'."

\section{Montesquieu}

$\mathrm{He}$ is one of the most famous thinkers among Europeans. His book titled "PersianLetters" and "The Spirit Of The Laws" have illustrated his thoughts. He was a thinker who devoted his thoughts to both European and non-European societies. He was more interested in social issues and political institutions than in art, literature, philosophy and models of thought. The more frequently used approach used by him was sociology rather than psychology. ${ }^{6}$

Montesquieu argued that a cultural diversity is an absolute character of human life. There are no two communities that are exactly similar. Each community has different customs, practices, ways, systems, laws, family structures and forms of government. Each encourages a difference of desire, morals, goodness, attitudes, forms of excellence and conception of good life. Although humans share the same nature, every society will develop along with different capacities and desires. ${ }^{7}$

When discussing social structure, Montesquieu distinguishes two terms that are often causing cultural, physical and moral plurality. Physically, humans will be different according to geographical conditions, soil conditions, climate, economy and so forth.

\footnotetext{
${ }^{4}$ Ibid., 52.

${ }^{5}$ Ibid.

${ }^{6}$ Ibid., 53.

${ }^{7}$ Ibid.
} 
Morally human will be divided into variations of its diversity according to the belief system held. Social and religious institutions have a significant influence in this moral formation.

When explaining cultural diversity, Montesquieu asserts that there are two frequently asked questions: explanation and normative. Explanation is an authentically explanation of the reality of the culture without any judgment or justification. In this case objectivity is required to be clearly demonstrated without any distortion, misinterpretation. Assumptions, prejudices and preconception should be removed far away when explaining the social reality. Montesquieu said "in all this I only give them a go, but do not justify their customs". ${ }^{8}$ The judgments are often included in the normative approach used in explaining reality. The normative approach puts forward "what should be" rather than "as it is". So normative often obscures objects, distorting objects from being unexplainably authenticated.

But what Montesquieu did does not fit with a conception he developed. Similar with Vico, he is more of a normative rather than an explanatory judgment. It is seen from the efforts of universal standardization of moral in diversity. The moral standard comes from three sources: the nature, the law, and the sociological analysis of human experience. According to him, the three sources that then led to the existence of standard morality referred to human development and nature. The universal morals include security, freedom, family stability, health, self-control, equality, justice, love, humanity, personal autonomy, the spirit of inquiry, tolerance, common law, equilibrium, gentleness, industry, and evasion of dogmatism, Strong beliefs. All of these are the qualities of life that universally become the basic human needs and desires. ${ }^{9}$

Montesquieu also holds the view that religion is the basis of social life, a pillar of morality that will help bring people to goodness. But religion should not be in a dogmatic, mysterious and mystical region. Within this framework, Montesquieu is almost identical to Vico in favor of Christianity as a legitimate religion as a social religious standard leading to a universal moral standards. Although in Christianity there are mystical elements, ascetic dogmatists, and other dimensions, Montesquieu asserts that Christianity should be approached intellectually, sensibly and morally honorable. ${ }^{10}$

This statement is criticized by Parekh in explaining the structure of the understanding of modern plurality. There is an inconsistency in principle. Both Vico and Montesquieu still have a mental 'major' in Western culture. So this culture that he considered appropriate to be standard for human life. In the dialectics of dominant culture and little culture, Europe for the two above thinkers must be put in a dominant culture

\footnotetext{
${ }^{8}$ Ibid.

${ }^{9}$ Ibid.

${ }^{10}$ Ibid.
}

Teosofia: Indonesian Journal of Islamic Mysticism, Volume 5, Number 2, 2016 
position. Therefore, other cultural values must be under the umbrella of Europe as a universal standard of cultural morality.

\section{Herder}

In principle, Herder rejected the monistic understanding used in viewing culture. That culture is a derivative invention of many different products from human being. It universally held human nature is a monistic view contrary to the fact that the differences in human nature are shaped by the multitude of different cultures.

Every culture has its own uniqueness. And the uniqueness according to Herder closely related to the myth (volk), ancestors, and offspring. The uniqueness arises from the understanding and impregnation of the people against these three things. The community environment plays an important role in shaping culture. It is not by causal means such as Montesquieu's thinking, but by structuring the world of experience in which it interprets and organizes the creative imagination of man. Thus, culture is a creative effort undertaken collectively by the community in understanding the myths that exist in society.

In understanding this cultural plurality, Herder focuses more on language. According to him, language is a cultural symbol in which there is an essence, cultural picture, and the value system prevailing in it. Language becomes a reflection of a society's culture. Ideas reflected in language are a just like mirror of the thoughts, feelings, memories, hopes and concerns of the community that show. ${ }^{11}$

One of his views which is quite interesting, is every culture according to him has equivalent value to other cultures. And the view of seniority, the majority, or the dominion according to him is wrong, incorrect view. Differences in cultural diversity usually lead to a denial of certain cultures, such as advanced cultural labeling (civilized culture) and uncivilized culture. The mistake of understanding this culture is actually the effect of a monistic view. Therefore, the school of cultural pluralism should propose the thesis of the similarity and tolerance between cultures, not discriminating or humiliating.

Although Herder's thought is quite interesting and shows the development of thinking about pluralism, Herder's view is not quite satisfactory. He still keeps the assumption of culture as a sealed knit and without the gap of the entire information tied with a principle or excessive spirit. As for example, no culture survived except primitive culture. In this view culture is divided by class, gender, regional line, or generation, and consists of several sequences of thought which are inherited historically and neatly arranged. Each is trying to claim its own ownership.

\footnotetext{
${ }^{11}$ Ibid., 68.
} 


\section{Misconception toward Understanding Culture}

Some misunderstandings about the position between pluralism and monism have tangled a few authors in previous discussions. Their pluralism approach often leaves a morality view as the key to understanding culture. Though morality is a keyword that is often used by monism. Morality often emphasizes the general principle that must be fixed in the overall value of culture. In this case, pluralism just rejected by itself. Therefore, the pluralism, they developed as if it has not been completely separated from the romanticism of monism that has been entrenched hundreds of years before.

Some of the weaknesses and misconceptions of the three thinkers above are described by Bhiku Parekh in detail as follows:

1. The three authors discussed above viewed that culture is an integrated and organic entity. They ignored the diversity and the tension within it. This fallacy is called the fallacy of holism.

2. They assumed that culture was a separate unit, having a soul, ethos, or organizational principle, and can be individualized and distinguished from one another. This fallacy is called the fallacy of distinctness.

3. They tend to have a static view of culture. Although appreciating that culture is a long historical product, they argued that from this moment onwards culture must be maintained more fully. As well as Vico and Montesquieu who argued that the culture of their day represents the highest achievement of man and marks the end of history. This mistake is called a positivistic, historical, or historical ending (positivist, historical or end-of-history fallacy).

4. They saw that every culture as an organic and unique expression of spirit, soul, national character, level of mental development, or the deepest desires and instincts of the society concerned. They had dominated cultures and communities by using anthropomorphic quasi points of view and they failed to explain why a community needs a certain character. This fallacy is called the fallacy of ethnicization of culture.

5. They had very conservative behavior towards culture. As long as the culture is deem as an integrating unity, the smallest change within it is considered to be full of unpredictable consequences. This fallacy is called the fallacy of closure.

6. They saw culture as a kind of self-acting collective agency that governs, demands, and expresses itself in a single body of beliefs and practices and follows its own internal laws and logic. Therefore their cultural theories leave a little space for freedom. This mistake is called the fallacy of cultural determinism. 
7. They separated from the broader economic and political structures of society. None of those three thinkers concerned with the ideological and political dimensions of culture and the complex ways in which the dominant interests determine, organize, and enforce them. Since each culture represents a particular worldview, and structuring relationships between people, culture tends to justify and maintain a certain kind of social order. This fallacy is called the fallacy of cultural autonomy.

\section{Multiculturalism as an Intercultural Bridge}

In response to the dialectic cycle between monism-pluralism which in carrying each thinking still leaves the weakness and the lack, then Parekh monk in this case issued a synthesis in the form of multiculturalism. Multiculturalism is the inevitability of cultural diversity in the structure and system of society. Multiculturalism recognizes not only diversity but also the recognition of uniqueness, strengths and weaknesses in every culture, including its own culture. So in this multiculturalism, one of the most prominent features is the intercultural dialogue.

Bhikhu Parekh pointed out that there are three notions of multiculturalism that are often interpreted:

1. Human culture is embedded in a social system, in the safe in it has built a social relations and law. This does not mean that humans are determined by their cultural system. It means they have no room to criticize it. It is rather on the formation of a deep humanitarian system in the structure of society, so they are more accepting of cultural heritage with little critical effort, because it is a practice that has been reflected in daily life.

2. Each culture will represent its own feature, and every culture has a meaning system and a good vision of life. When every culture recognizes human limitations and realizes the vastness of human existence, it will need others (culture) to lead to a better understanding. Culture, therefore, does not accept comparisons that lead to justification, but rather on equality that leads to respect, that every culture has a plus for its members. Thus, there is no perfect culture which has the right to impose its will to be applied in other cultures.

When justification does not exist, then what will appear is a positive dialogue that will reduce the biases and negative assumptions to a particular culture. Through dialogue they will open the insight or horizons of thought. And this certainly has a positive effect in intercultural reciprocity. They can learn from other people's culture to take positive values which are then brought into their own culture. 
3. Almost in all primitive cultures, internally they have plural differences and represent the continuity of communication between their different traditions. This is not exactly the absence of their identity; it is the diversity that becomes the identity. A culture will grow with awareness and without awareness by interacting socially with others. From this interaction they will take something significant which is then applied in his life. This is what underlies the assimilation between cultures while maintaining the 'genuineness' (uniqueness in the locality of culture) of society.

With a multicultural perspective, there is no political or ideological doctrine that plays a single truth role in human life. Either it is socialism, liberalism, conservatism, or nationalism, all of this is a culture formed in society, which represents a 'part' of the vision of a good life. For example liberalism inspires in its political doctrine of human dignity, autonomy, freedom, critical thinking and equality. Liberalism, however, is part of the visionary of a good vision of life. Because not all values promoted by liberalism have a coherence intact. There are other values that may be complementary not found in liberalism, such as human solidarity, equal opportunity, humility, contentment, and so on. With the perspective of multiculturalism, dialogue will make human life more open, critical and dynamic.

\section{E. Multiculturalism with Qur'an Perspective}

The Qur'an as a guide of mankind, Muslims in particular, occupies an important position in shaping the character of its readers, because the Qur'an has a guidance function. It is by this function that al-qur'an becomes the central and mainstay of Muslim thought.

In the Qur'an itself there are various verses that may be referred to as cues about multiculturalism, pluralism and monism. For example about multiculturalism Quran mentioned a word, 'li ta'arafü' in the author's view, the verse preserves a signal about the existence of multiculturalism. While the verse of pluralism can be seen from "if Allah wills Allah will make you as one community with "one color ", one style and one flag, but God does not want so. The verses of monism can be seen from exclusive verses, such as inna aldìn 'inda Allāh al-Islām and wa man yabtaghighair al-Islām dỉna falā yuqbala minh.

Analyzing some examples above, it is very apparent that in the Qur'an there are various styles emphasized, there is pluralism, there is monism, and there is multiculturalism. Then how to make a dialogue those three types, but they have a principal difference in the value contained therein. Let's say how to dialogue between verses of pluralism and monism. On the one hand the Qur'an places pluralism and on the other hand it places monism. Are there any special areas behind the emphasis of these verses, or are the verses that seem to contradict collaborate and have a specific mission, or do each have a special mission emphasized so that a major mission of the verses can be found. And the 
main question is what exactly is the mission carried by the Qur'an? Is it pluralism or monism?

To look at these conflicting verses, it requires appropriate methodologies to be able to uncover the hidden impasse. Among the methodologies that can be used are Hermeneutics, historicity of verse, munāsabah al-äyah (conformity of verse), thematic.

\section{F. Conclusion}

The fallacies that have been mentioned basically explain that their pluralistic view has not fully depicted a cultural diversity yet in a pluralistic view. Because they still use a view of cultural integration to facilitate the cultural identification. This view ultimately makes culture an autonomous life zone and forgets its interrelation in broader political, social and economic structures. The task faced by the theorists of cultural diversity is how to assess cultural interests, strengths and coherence without making the mistakes described above. Through the perspective of multiculturalism, all cultures will be placed in accordance with their position as a culture that has the characteristics of sui generis (uniqueness in every culture). So intercultural will be aware of the advantages and disadvantages which will then serve an open and constructive dialogue process. 


\section{Bibliography}

Parekh, Bhikhu, Rethinking Multiculturalism Cultural Diversity and Political Theory, Cambridge: Harvard University Press, 2000.

Tillich, Paul, Teologi Kebudayaan Tendensi, Aplikasi dan Komparasi, trans. Miming Muhaimin, Yogyakarta: IRCiSoD, 2002.

Hefner, Robert W. (ed.), Politik Multikulturalisme Menggugat Realitas Kebangsaan, trans. Bernardus Hidayat, Yogyakarta: Penerbit Impulse-Kanisius, 2007. 
114 